\title{
The Effects of the Emotion adjustment and School adaptation of the Children of the Families that Broke Away from North Korea
}

\author{
*Kim Minkyeong, Professor, Department of Child Welfare, Namseoul University, 91 Daehakro \\ Sunghwaneup Seobukgu Cheonan City, 31020, South Korea, ilu35@hanmail.net
}

\begin{abstract}
A recent trend of North Korean defectors is that an increasing number of them defect from North Korea and come to Korea as a family unit. Thus, the present research aims to examine whether the play-oriented group counseling program would help increase North Korean defector children's ability to control emotions and to get adjusted to school life. Subjects were 10 elementary school students. Ability to control emotions was measured by Mayer \& Salovey model of emotional intelligence. Adaptation to school life was measured by Eun's scale. Among nonparametric statistical methods, the Mann-Whitney U Test and the Wilcoxon Singed-Rank Test were conducted by SPSS 20.0. The results of this study are summarized as follows. A group program is effective in improving the emotional adjustment. Statistically significant differences were shown in all three lower-level elements of emotional adjustment. it was found that the CPRT program had a significantly positive impact on North Korean defector children's ability to control emotions and adaptation to school life. This study has significance in terms that it proved the effects of a group program on the empowerment of broke away from North Korea children, and the effects were confirmed by an experimental study.
\end{abstract}

Keywords: North Korea, group program, school adaptation, emotion adjustment, Broke away, Children Received: 09.12.2020 Accepted: 10.01.2021 $\quad$ Published: 06.02.2021

\section{INTRODUCTION}

As of 2018, the total number of North Korean defectors is 31,827, of which 4,107 are children or adolescents younger than 19[1]. A recent trend of North Korean defectors is that an increasing number of them defect from North Korea and come to Korea as a family unit. Therefore, researches on the life of the young children of such families are very important.

A recent trend of North Korean defectors is that an increasing number of them defect from North Korea and come to Korea as a family unit. Therefore, researches on the life of the young children of such families are very important. Previous researches have reported, as expected, that these defector children struggle with a variety of problems of school life: difficulty in getting adjusted to different educational systems and curriculum, lack of basic learning skills, different social and cultural environments, and difficulty in establishing peer relationship[2].

As the mechanisms influencing young North Korean defectors' psychological/emotional aspects and their adaptation to school life might vary[3], it seems indispensable to apply various psychological approaches to such children. However, we have not seen enough researches conducted with such a perspective.

The severe tension and anxiety that they had to go through during the process of defection would lead to these defector children's emotional instability. The defector parents, on the other hand, would face marital conflicts owing to different gender roles and financial difficulties after entry to Korea, which often cause them to get divorced[4].

The most frequent and serious problem of North Korean defector children is their adaptation to school life [5]. The defector children have to struggle with others' fixed ideas and prejudice against them as well as their own problems of social relationship and academic adjustment. In contrast, excessive curiosity and sympathy toward these children might contribute to others of them[6]. Such psychological/emotional difficulties and academic underachievement often resulting from a blank period in education would top the list of sources of their trouble and problems.

Most of the defector children live with a single parent or grandparents and have hard time in getting adjusted to different educational systems and values of Korean society. The consequent instable family environment is often neglected and leads them to increasing psychological stress at school and in society. They do not know how to solve such problems and conflicts, protect themselves and control their emotions, which would, as a consequence, result in troubles with peers[7].

As the mechanisms influencing young North Korean defectors' psychological/emotional aspects and their adaptation to school life might vary[8], it seems indispensable to apply various psychological 
approaches to such children[9]. However, we have not seen enough researches conducted with such a perspective. Also, it should be noted that few researches have been conducted with a focus on plays, which can be rather intimately applied to such young people.

Thus, the present research aims to examine whether the play-oriented group counseling program would help increase North Korean defector children's ability to control emotions and to get adjusted to school life. The results of analysis are expected to provide base data that can be used in the field to help such young children increase such ability.

\section{Methods}

\subsection{Subjects}

This study was conducted in first-, second-, and third-graders from multicultural families at S Multicultural Family Support Center in Wonju, Gangwon Province, at C Multicultural Family Support Center in Cheonan, South Chungcheong Province, and at U Elementary School in Dangjin who intended to participate in play-based self-awareness training. A total of 13 children formed the experimental group and 12 formed the control group.

\subsection{Tools}

\subsubsection{Ability to control emotions}

Their ability to control emotions was measured by Mayer \& Salovey model of emotional intelligence[10]. The tool consisted of a total of 15 measurement items: 7 of them pertaining others' emotion and 8 of them for their own emotion. Other's emotion includes intimate relationship with friends and positively recognizes environment. Self-emotion includes controlling and regulating own emotion. Each item was measured on a four-point scale: 1 for strongly disagree, 2 for disagree, 3 for agree, and 4 for strongly disagree. Cronbach's $\alpha$ was 92 .

\subsubsection{Adaptation to school life}

The subjects' adaptation to school life was measured by adopting Eun's scale[11]. The tool consisted of a total of 38 items with four categories. Adapatation to school life includes studying at school, establishing relationships with friends at school, establishing relationships with teachers, and satisfaction with school life. Each item was measured on a four-point scale: : 1 for strongly disagree, 2 for disagree, 3 for agree, and 4 for strongly disagree. School adaptation scale used [4]'s a total of 38 items. Cronbach's $\alpha$ was .92 .

\subsection{Data processing and analysis}

Since the number of cases in this study-13 in the experimental group and 12 in the control group-is hard to meet the assumption of regular distribution for measurements, a non-parametric statistical method, which requires no basic assumption of regular distribution, was used. SPSS version 20.0 for Windows was used for data analysis to verify the effects of the training program. Among nonparametric statistical methods, the Mann-Whitney U Test and the Wilcoxon Singed-Rank Test were conducted.

\section{Results}

\subsection{Homogeneity}

Wilcoxon signed rank test is more powerful than sign test when paired two group's difference verification.

$$
\begin{aligned}
& \mathbf{Z}=\frac{\mathrm{T}-\frac{\mathrm{N}(\mathrm{N}+1)}{4}}{\sqrt{\frac{\mathrm{N}(\mathrm{N}+1)(2 \mathrm{~N}+1)}{\mathrm{N}-1}}} \\
& \text { Mann-Whitney U test is used because of simplification of test. } \\
& \mathrm{U}_{1}+\mathrm{U}_{2}=\mathrm{n}_{1} \mathrm{n}_{2}+\mathrm{n}_{1} \mathrm{n}_{2}+\frac{\mathrm{n}_{1}\left(\mathrm{n}_{1}+1\right)}{2}+\frac{\mathrm{n}_{2}\left(\mathrm{n}_{2}+1\right)}{2}-\left(\Sigma^{\mathrm{R}_{1}}+\Sigma^{\mathrm{R} 2}\right) \\
& \mathrm{n}_{1} \mathrm{n}_{2}+\frac{\mathrm{n}_{1}\left(\mathrm{n}_{1}+1\right)}{2}+\frac{\mathrm{n}_{2}\left(\mathrm{n}_{2}+1\right)}{2}=\Sigma^{\mathrm{R}_{1}}+\Sigma^{\mathrm{R} 2}=\mathrm{T} \\
& \text { so, } \mathrm{U}_{1}+\mathrm{U}_{2}=\mathrm{n}_{1} \mathrm{n}_{2}
\end{aligned}
$$


Table 1. Homogeneity of emotional adjustment and school adaptation

\begin{tabular}{|c|c|c|c|c|c|c|c|}
\hline & Group & $\mathrm{N}$ & $\begin{array}{l}\text { Mean } \\
\text { order }\end{array}$ & $\begin{array}{l}\text { Sum } \\
\text { Order }\end{array}$ & $\begin{array}{l}\text { of Mann- } \\
\text { Whitney U }\end{array}$ & $\mathrm{Z}$ & $\mathrm{p}$ \\
\hline \multirow{2}{*}{$\begin{array}{l}\text { Emotional } \\
\text { adjustment }\end{array}$} & Experimental & 10 & 11.90 & 119.00 & & & \\
\hline & Control & 10 & 9.10 & 91.00 & & & \\
\hline \multirow{2}{*}{$\begin{array}{l}\text { School } \\
\text { adaptation }\end{array}$} & Experimental & 10 & 12.20 & 121.00 & \multirow{2}{*}{38.000} & \multirow{2}{*}{-.496} & \multirow{2}{*}{.620} \\
\hline & Control & 10 & 8.80 & 89.00 & & & \\
\hline
\end{tabular}

The analysis of the homogeneity of the two groups in their ability to control emotions found that the mean rank of the experimental group was 11.90 in contrast to 9.10 of the control group as shown in Table 1. Thus, the difference was not statistically significant, verifying the homogeneity of the two groups in their emotional control ability before the play-oriented group counseling program was conducted.

As for the subjects' adaptation to school life, it was also found that the two groups showed no significant difference: the mean ranks of the experimental group and the control group were 12.200 and 8.800, respectively. Thus, it might be assumed that homogeneity was secured between the two groups in terms of adaptation to school life.

\subsection{Difference of emotion adjustment}

Difference of emotion adjustment children showed Table 2. was significantly different positive rank of emotion adjustment was 10. negative rank of emotional adjustment was 0 . Therefore, it means that positive change children was much better than negative changing broke away children.

A pretest and a posttest were given to the subjects of both groups to examine the influence of the playoriented group counseling program might have on the North Korean defector children's ability to control emotions.

Wilcoxon signed rank Test was conducted to the experimental group to compare the measurements of the pretest and the posttest in their ability to control emotions. It was found that the mean rank of the cases whose measurements were greater at the posttest than the pretest was 5.50 and that of the opposite cases was 0.00 . The difference was statistically significant at the level of $p<.01$, which indicates that the play-oriented group counseling program had a positive effect on the experimental group's ability to control emotions.

\subsection{Difference of school adaptation}

Difference of emotion school adaptation multicultural children showed Table 3. was significantly different positive rank of school adaptation was 10 . Negative rank of school adaptation was 0 . Therefore, it means that positive change children was much better than negative changing broke away children.

Wilcoxon signed rank Test found that all the 10 cases of the experimental group marked a plus value and no minus value in their adaptation to school life. The cases whose measurements were greater at the posttest than the pretest recorded a mean rank of 5.50, whereas the mean rank of those with a lesser result at the posttest was 0.00 . This difference was statistically significant at the level of $\mathrm{p}<.01$. Therefore, it might be safe to conclude that the CPRT program exerted a positive effect on the experimental group's adaptation to school life.. As in Table 13, a plus value indicates that the measurement of the posttest is greater than that of the pretest.

Table 2. Difference of emotion adjustment change before and after program intervention 


\begin{tabular}{|c|c|c|c|c|c|}
\hline $\begin{array}{l}\text { Experimental } \\
\text { group } \\
(\mathrm{N}=10)\end{array}$ & & $\mathrm{N}$ & $\begin{array}{l}\text { Average } \\
\text { Rank }\end{array}$ & $\begin{array}{l}\text { Sum of } \\
\text { Rank }\end{array}$ & $\mathrm{z}$ \\
\hline \multirow{4}{*}{$\begin{array}{l}\text { Total Emotion } \\
\text { adjustment }\end{array}$} & negative rank ${ }^{\mathrm{a}}$ & 0 & .00 & .00 & \multirow{4}{*}{$-2.81^{* *}$} \\
\hline & positive rank ${ }^{\mathrm{b}}$ & 10 & 5.50 & 55.00 & \\
\hline & $\mathrm{tie}^{\mathrm{c}}$ & 0 & & & \\
\hline & Total & 10 & & & \\
\hline \multirow{4}{*}{$\begin{array}{l}\text { Self Emotion } \\
\text { control }\end{array}$} & negative rank ${ }^{\mathrm{a}}$ & 0 & .00 & .000 & \multirow{4}{*}{$-2.82^{* *}$} \\
\hline & positive rank ${ }^{\mathrm{b}}$ & 10 & 5.50 & 55.00 & \\
\hline & tie $^{c}$ & 0 & & & \\
\hline & Total & 10 & & & \\
\hline \multirow{4}{*}{$\begin{array}{l}\text { Other Emotion } \\
\text { control }\end{array}$} & negative rank ${ }^{\mathrm{a}}$ & 0 & .00 & .00 & \multirow{4}{*}{$-2.81^{* *}$} \\
\hline & positive rank ${ }^{\mathrm{b}}$ & 10 & 5.50 & 55.00 & \\
\hline & $\mathrm{tie}^{\mathrm{c}}$ & 0 & & & \\
\hline & Total & 10 & & & \\
\hline
\end{tabular}

** $\mathrm{p}<.01$ a. posttest<pretest, b. posttest $>$ pretest, c. posttest=pretest

Table 3. Difference of school adaptation change before and after program intervention

\begin{tabular}{|c|c|c|c|c|c|}
\hline $\begin{array}{l}\text { Experimental } \\
\text { group } \\
(\mathrm{N}=10)\end{array}$ & & $\mathrm{N}$ & $\begin{array}{l}\text { Average } \\
\text { Rank }\end{array}$ & $\begin{array}{l}\text { Sum of } \\
\text { Rank }\end{array}$ & $\mathrm{Z}$ \\
\hline \multirow{4}{*}{$\begin{array}{l}\text { Total School } \\
\text { adaption }\end{array}$} & $\begin{array}{l}\text { negative } \\
\text { rank }^{a}\end{array}$ & 0 & .00 & .000 & \multirow{4}{*}{$-2.807^{* *}$} \\
\hline & $\begin{array}{l}\text { positive } \\
\text { rank }^{\mathrm{b}}\end{array}$ & 10 & 5.50 & 55.000 & \\
\hline & $\mathrm{tie}^{\mathrm{c}}$ & 0 & & & \\
\hline & total & 10 & & & \\
\hline \multirow{3}{*}{ School Study } & $\begin{array}{l}\text { negative } \\
\text { rank }^{a}\end{array}$ & 0 & .00 & .000 & \multirow{3}{*}{$-2.807^{* *}$} \\
\hline & $\begin{array}{l}\text { positive } \\
\text { rank }^{\mathrm{b}}\end{array}$ & 10 & 5.50 & 55.000 & \\
\hline & $\mathrm{tie}^{\mathrm{c}}$ & 0 & & & \\
\hline
\end{tabular}




\begin{tabular}{|c|c|c|c|c|c|}
\hline & total & 10 & & & \\
\hline \multirow{4}{*}{$\begin{array}{l}\text { School } \\
\text { Friends }\end{array}$} & $\begin{array}{c}\text { negative } \\
\text { rank }^{\mathrm{a}}\end{array}$ & 0 & .00 & .00 & \multirow{4}{*}{$-2.81^{* *}$} \\
\hline & $\begin{array}{c}\text { positive } \\
\text { rank }^{b}\end{array}$ & 10 & 5.50 & 55.00 & \\
\hline & $t^{t i} e^{c}$ & 0 & & & \\
\hline & total & 10 & & & \\
\hline \multirow{4}{*}{$\begin{array}{l}\text { School } \\
\text { Teacher }\end{array}$} & $\begin{array}{l}\text { negative } \\
\text { rank }^{\mathrm{a}}\end{array}$ & 0 & .00 & .00 & \multirow{4}{*}{$-2.81^{* *}$} \\
\hline & $\begin{array}{l}\text { positive } \\
\text { rank }^{\mathrm{b}}\end{array}$ & 10 & 5.50 & 55.00 & \\
\hline & $\mathrm{tie}^{\mathrm{c}}$ & 0 & & & \\
\hline & total & 10 & & & \\
\hline \multirow{4}{*}{ School Life } & $\begin{array}{l}\text { negative } \\
\text { rank }^{\mathrm{a}}\end{array}$ & 0 & .00 & .00 & \multirow{4}{*}{$-2.81^{* *}$} \\
\hline & $\begin{array}{l}\text { positive } \\
\text { rank }^{\mathrm{b}}\end{array}$ & 10 & 5.500 & 55.000 & \\
\hline & $\mathrm{tie}^{\mathrm{c}}$ & 0 & & & \\
\hline & total & 10 & & & \\
\hline
\end{tabular}

${ }^{* *} \mathrm{p}<.01$ a. posttest<pretest, b. posttest $>$ pretest, c. posttest=pretest

\section{Discussion and Conclusion}

First of all, it was found that the CPRT program had a significantly positive impact on North Korean defector children's ability to control emotions and adaptation to school life.

Second, it is recommended that the play-oriented group counseling program be run by counseling experts in the institutions dealing with North Korean defector children. Then, they would be more likely to have a deeper understanding of such children's problems and needs, which would eventually help solve them. That is, with a deep understanding of the defector children's socio-cultural characteristics, psychological intervention would be possible for other issues than emotional control and adaptation to school life.

Also, structured counseling programs would help school teachers have a better understanding of the defector children, which would eventually help them better support the children in getting adjusted to school life.

A few limitations of the current research should be admitted. First, the research subjects who have only lived in Korea for a short period of time had language problem as well as cultural barrier. Thus, in order to have a smoother progress, the research tools were translated into Chinese by some experts in the Chinese language. Still, however, it was not easy for the children to understand the whole program owing to cultural differences. Thus, it seems necessary that the play-oriented group counseling program be revised in order to consider and reflect the cultural and linguistic characteristics of North Korean defector children.

Second, the present research proceeded with the children of $5^{\text {th }}$ to $6^{\text {th }}$ graders. Further researches should be expanded to children of various age groups, considering that the number of children defecting from North Korea is on the increase and that about $20 \%$ of such defector children are preschool children in 2017 (South North One Foundation, 2018).

Third, the current research identified a variety of problems and needs of North Korean defector families. It was pointed out that many family problems were attributable in the differences between husband and wife, and between parents and children in getting adjusted to a new environment in Korea (Y. Kim, 2004). Therefore, psychological and educational intervention seems be indispensable for the 
parents of such families. Also, we should keep providing special care and family counseling for single parent families and those without family.

\section{Acknowledgment}

Funding for this paper was provided by Namseoul University.

\section{References}

[1] Aldao A, Nolen-Hoeksma S, When are adaptive strategies most predictive of psychopathology?. Journal of Abnormal Psychology. 2010 121: 276-81.

[2] Gross JJ, Antecedent-and response-focused emotion regulation: divergent consequences for experience, expression, and physiology. Journal of Personality and Social Psychology.1998 74(1):224-37.

[3] Gross JJ, Emotion regulation: Current status and future prospects. Psychological Inquiry. 2015 26: $1-26$.

[4] Shin SN, Yu SH, Jo HS, A Study of the Social Adaptation Process for Young Korean Refugees Represented in Children's Storybooks. Journal of Eco Child Education Research. 2008 7(2):41-57. http://www.ndsl.kr.proxy.nsu.ac.kr:8010/ndsl/search/detail/article/articleSearchResultDetail.do?c $\mathrm{n}=\mathrm{ART} 001272881$

[5] McLaughlin KA, Hatzenbuehler ML, Mennin DS, Nolen-Hoeksema S, Emotion dysregulation and adolescent psychopathology: A prospective study. Behaviour Research and Therapy. 2011 49(9):544-54.

[6] Campos JJ, Frankel CB, Camras L. On the nature of emotion regulation. Child Development. 2004 75: 377-94.

[7] Calkins SD, Commentary: Conceptual and methodological challenges to the study of emotion regulation and psychopathology. Journal of Psychopathology and Behavioral Assessment. 2010 32:92-5.

[8] Barton WH, Juvenile justice policies and programs. Social Policy for Children \& Families: A Risk and Resilience Perspective. 2006: 231-264.

[9] Morris WW, Relly NP, Toward the self-regulation of mood: Theory and research. Motivation and Emotion. 1987 11:215-49.

[10] Mayer JD, Salovey P, Emotional Intelligence. Imagination Cognition and Personality, 1990 9(3):185-211.

[11] Eun SK, A study on influencing on multicultural children's school adaptation: Focusing on mediating family function. [dissertation].[Seoul]:Sungsil University; 2009. 